\title{
Influences of river flow on the dynamics of phytoplankton production in a partially stratified estuary*
}

\author{
T. C. Malone, L. H. Crocker, S. E. Pike, B. W. Wendler \\ Horn Point Environmental Laboratories, University of Maryland Center for Environmental and Estuarine Studies, PO Box 775, \\ Cambridge, Maryland 21613, USA
}

\begin{abstract}
The mesohaline reach of Chesapeake Bay (USA) receives most of its allochthonous nutrient input from a single source, the Susquehanna River. Seaward of the turbidity maximum, concentrations of dissolved inorganic nutrients decrease rapidly as phytoplankton biomass increases along the salinity gradient. The annual cycle of riverine nutrient input is in phase with phytoplankton biomass but out of phase with phytoplankton productivity in this region. Riverine nutrient input and phytoplankton biomass peak during spring, but phytoplankton productivity peaks during summer. Seasonal variations in biomass are correlated with riverine nitrate input while seasonal variations in productivity are correlated with light and temperature. Evidence is presented which suggests that the spring flux of nitrogen from the watershed and the summer productivity maximum are coupled via the accumulation and sedimentation of phytoplankton biomass during spring and subsequent recycling of regenerated nitrogen into the euphotic zone during summer. We conclude that the occurrence of maximum productivity during summer in the mesohaline reach of the Bay is a consequence of the recycling of nitrogen delivered to the system during the previous spring. Inter-annual variations in the magnitude of the summer productivity maximum appear to be related to variations in vertical stratification which influences the vertical flux of regenerated ammonium from the benthos to the euphotic zone. In this context, the extent of seasonal oxygen depletion during summer appears to be determined by riverine nitrate input during the spring freshet and the strength and variability of vertical stratification during summer.
\end{abstract}

\section{INTRODUCTION}

The response of plankton communities to nutrient enrichment in coastal ecosystems is of major significance in marine ecology and has broad implications in terms of both water quality and fisheries. Anthropogenic nutrient inputs to estuaries have increased rapidly over the last 3 to 4 decades (e.g. Walsh et al. 1981. Nixon \& Pilson 1983). Such increases have been shown to stimulate phytoplankton production in estuarine systems (Nixon 1981, Boynton et al. 1982, Cadee 1986). Partially stratified estuaries are likely to be particularly responsive to nutrient enrichment as a consequence of 2-layered flow regimes which potentially increase the retention and recycling of nutrients (Redfield 1955, Ketchum 1967, Taft et al. 1978). The high productivity and temporal and spatial lags

- UMCEES Contribution No. 1920

(c) Inter-Research/Printed in F. R. Germany between nutrient inputs and phytoplankton production which often characterize estuarine systems have been attributed to this phenomenon (Nixon 1981, Boynton et al. 1982, Nixon \& Pilson 1983, Kemp \& Boynton 1984, Flint et al. 1986). However, the time and space scales on which nutrient inputs are related to nutrient recycling and primary productivity are not well documented. Thus, while it is generally observed that nutrient inputs from external sources can cause nonlinear increases in phytoplankton production (Eppley \& Peterson 1979 , Platt \& Harrison 1985), time-dependent relations between the input of nutrients and phytoplankton productivity are poorly understood in estuaries.

Annual phytoplankton production in Chesapeake Bay appears to be more sensitive to nitrogen than to phosphorus loading. In summarizing data on estuarine production and nutrient loading, Boynton et al. (1982) found a better correlation between annual phytoplankton production and nitrogen loading than between 
production and phosphorus loading. More recently, Fisher et al. (in press) observed that nitrogen input to the Bay is removed more efficiently than phosphorus input. While most of the input of dissolved inorganic nitrogen was assimilated and transformed to organic nitrogen within the Bay, total phosphorus and the partitioning of phosphorus among dissolved inorganic and total organic phases showed little net change between freshwater and seawater end members on average Liss (1976) has interpreted such phosphorus distributions in estuaries as an indication of rapid recycling and the 'buffering' effect of adsorption-desorption reactions which partition phosphate between dissolved and particulate phases.

The major external source of nitrogen to Chesapeake Bay is the Susquehanna River (Carpenter et al. 1969, Flemer et al. 1985), which supplies more than $80 \%$ of the total nitrogen input to the upper Bay (Fig. 1), mainly in the form of nitrate (McCarthy et al. 1977. Harding et al. 1986, Schubel \& Pritchard 1986). As is typical of mid-latitude rivers, the annual cycle of fresh water discharge exhibits a spring maximum and a summer minimum. Consequently, 50 to $60 \%$ of the annual nitrogen input to the upper Bay occurs during the spring freshet (Schubel \& Pritchard 1986). Most of this external supply of nitrogen is assimilated downstream of the turbidity maximum in the mesohaline reach of the Bay where phytoplankton productivity and chiorophyll a concentration also achieve their spatial maxima (Harding et al. 1986, Fisher et al. in press), a pattern which probably reflects light-limited nutrient uptake and productivity (Flemer 1970, McCarthy et al. 1974, 1977, Harding et al. 1986). Seasonal variations in phytoplankton productivity also appear to be light dependent with a winter minimum and a summer maximum (Flemer 1970, Taft et al. 1980, Boynton et al. 1982). Thus, the annual cycle of nutrient delivery and phytoplankton productivity are seasonally out of phase with maximum phytoplankton productivity occurring 2 to 4 mo after the spring freshet (Flemer 1970, Taft et al. 1980, Boynton et al. 1982).

Primarily on the basis of this lag and on assumptions concerning the decay rate of organic matter in Chesapeake Bay, Taft et al. (1980) and Officer et al. (1984) concluded that seasonal oxygen depletion in Chesapeake Bay is a response to the previous years' phytoplankton production. In contrast, based on observations which suggest that the annual cycles of phytoplankton productivity, temperature and nitrogen regeneration are in phase (Kemp \& Boynton 1981, Boynton \& Kemp 1985), Boynton et al. (1982) and Kemp \& Boynton (1984) proposed a conceptual model relating summer phytoplankton productivity to spring nitrogen supply via organic deposition and temperature-dependent nitrogen regeneration. However, the mechanisms by which nutrients are recycled between sources and sinks on a seasonal time scale are not known. Malone et al. (1986) proposed a mechanism by which nutrients regenerated below the pycnocline could be returned to the euphotic zone at sufficiently high rates to support high summer productivity. This involves lateral oscillations of the pycnocline and associated variations in vertical mixing and advection. A second aspect of the problern is how the spring delivery of nitrate is related to summer ammonium regeneration.

Since phytoplankton account for most of organic input downstream of the turbidity maximum (Biggs \& Flemer 1972), the most likely process is phytoplankton assimilation and the accumulation of sufficient biomass to fuel summer regeneration. However, this seems to be contrary to the notion that the annual cycles of phytoplankton productivity and biomass are in phase (Flemer 1970, Taft 1980, Boynton et al. 1982, Harding et al. 1986). Kemp \& Boynton (1984) speculate that dissolved inorganic nitrogen input is transformed to particulate nitrogen via sorption, flocculation and assimilation in the region of the turbidity maximum and that downstream sedimentation provides the source of nitrogen for subsequent summer recycling. However, the spatial distribution of nitrate and salinity indicate that most of the nitrate flux is assimilated downstream of the turbidity maximum in the mesohaline reach of the Bay (McCarthy et al. 1977. Harding et al. 1986, Schubel \& Pritchard 1986). Most field programs in the Bay have been more concerned with spatial variations along the longitudinal salinity gradient than with lateral or seasonal variations. Our purpose here is to address the problem of how seasonal variations in phytoplankton biomass and productivity in the mesohaline reach of the Bay are related to the riverine input of nitrogen and to nitrogen recycling within the Bay.

\section{METHODS}

Samples were collected at 16 stations along 4 transects of the mesohaline reach of Chesapeake Bay (Fig. 1). Three transects were oriented normal to the main axis of the Bay (east-west). The 4 th transect was located in the channel of the main axjs of the Bay (north-south). Channel stations ranged in sonic depth from 25 to $42 \mathrm{~m}$. Sampling rate varied with time of year, ranging from a minimum of 1 cruise per month during fall and winter to a maximum of 4 cruises per month during spring. The Chop-Pax transect (T2 in Fig 1) was sampled more frequently than the transects to the north and south. Stations were often occupied more than once per cruise, in which case results were averaged for the purposes of this analysis. Vertical profiles of 


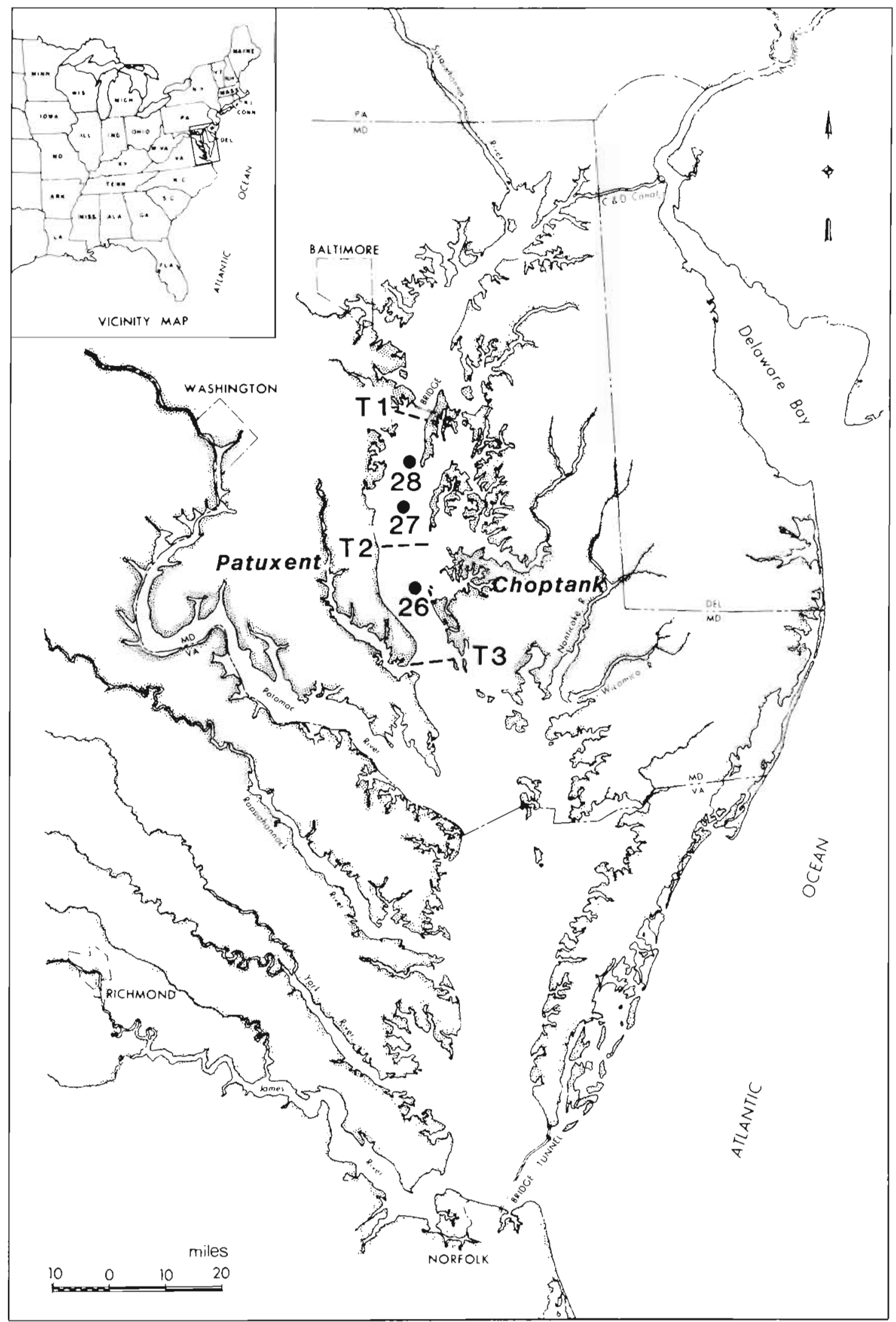

Fig. 1. Location of east-west (lateral) transects and channel stations between transects in the mesohaline reach of Chesapeake Bay 
temperature, salinity, dissolved oxygen, dissolved inorganic nutrients, chlorophyll $a$, and particulate organic carbon and nitrogen were determined at all stations. Phytoplankton productivity was measured at Stations 01, 03, and 05 of the Chop-Pax transect. Data on the freshwater discharge of the Susquehanna River were provided by the United States Geological Survey based on gauged flow at the Conowingo Dam located $90 \mathrm{~km}$ upstream of the study area.

This sampling scheme emphasizes temporal and lateral variability for a variety of reasons: (1) Effects of nutrient enrichment are greatest in the mesohaline reach of the Bay between $39^{\circ} \mathrm{N}$ and $38^{\circ} 20^{\prime} \mathrm{N}$ where phytoplankton productivity and biomass are highest and summer oxygen depletion is most extensive (Flemer 1970, McCarthy et al. 1977, Taft et al. 1980, Harding et al. 1986, Schubel \& Pritchard 1986, Fisher et al. in press). (2) Significant lateral (east-west) variations occur in the distributions of nutrients and chlorophyll which appear to be related to depth and to timedependent variations in density structure normal to the main axis of the Bay (Tyler 1984, Malone et al. 1986). (3) Spatial variations in chlorophyll concentration account for most variability in phytoplankton productivity along the salinity gradient of the Bay (Harding et al. 1986).

Water samples were collected with a submersible well pump equipped with a $2.5 \mathrm{~cm}$ diameter hose. Temperature, salinity, dissolved oxygen and in vivo chlorophyll fluorescence were measured at $1 \mathrm{~m}$ intervals. In vivo chlorophyll fluorescence were measured with a Turner Designs fluorometer. Temperature, salinity and dissolved oxygen were measured in 1985 using a YSI model 57 DO meter and YSI model 33 salinity meter and, in 1986, using a thermosalinograph equipped with a Sea-Bird Electronics model 3-01/S temperature sensor and model 4-01/0 conductivity meter Water samples for particulate organic and dissolved inorganic nutrient analyses were collected at 2 to 6 depths depending on depth and the vertical profiles of salinity and in vivo chlorophyll fluorescence. Particulate organic carbon and nitrogen were determined with a Controlled Equipment model 240-XA elemental analyser, chlorophyll a with a Turner Designs fluorometer following extraction with $90 \%$ acetone, and dissolved inorganic nutrients with a Technicon autoanalyser following filtration. Particulates were collected by filtration under low vacuum $(<130 \mathrm{~mm} \mathrm{Hg})$ on $\mathrm{GF} / \mathrm{F}$ glass fiber filters (pre-combusted for organic carbon and nitrogen). Biomass ratios of carbon, nitrogen, and chlorophyll were estimated as described by Chervin et al. (1981).

Phytoplankton productivity was estimated by the ${ }^{14} \mathrm{C}$ technique from $24 \mathrm{~h}$ incubations under natural sunlight. Total dissolved inorganic carbon was measured with a
Beckman model 864 infrared analyser after acidification. Samples were collected from a depth of $1 \mathrm{~m}$ and incubated at surface water temperature under light levels of $100,50,25,9$, and $1 \%$ of surface irradiance. Incubations were initiated within 2 h of sunrise. Samples were filtered onto GF/F filters under low vacuum, rinsed with filtered estuarine water, acidified with $30 \mu \mathrm{l}$ of glacial acetic acid, and placed in scintillation vials with $10 \mathrm{ml}$ of Ready-Solv, ${ }^{14} \mathrm{C}$ activity was measured with an LKB 1212 RackBeta liquid scintillation counter. Euphotic zone productivity was calculated as described by Malone et al. (1986). Briefly, the $1 \%$ light depth, determined with a Secchi disc and a LICOR submarine quantum meter, ranged from 3 to $12 \mathrm{~m}$ (mean $=5 \mathrm{~m}$ ) and was located in or above the pycnocline. Given the difficulties of collecting samples from precise light depths in such shallow euphotic zones, phytoplankton productivity at the above percent light depths was calculated as the product of chlorophyll specific productivity at each light level and chlorophyli concentration at the corresponding light depths. Euphotic zone productivity was then calculated by integrating between the surface and $1 \%$ light depth. This procedure ignores the influence of adaptation to low light levels near the base of the euphotic zone. However, it has been our experience that vertical variations in productivity are primarily a function of light and chlorophyll concentration and that light adaptation is a secondary effect. As discussed by Malone (1982a), 24 h incubations provide reasonable estimates of net particulate organic productivity in nutrient-rich environments.

\section{ANNUAL CYCLES OF FRESHWATER FLOW AND NITRATE SUPPLY}

The volume transport of freshwater into the mesohaline reach of the Bay influences the production of phytoplankton biomass through its effects on (1) supply of allochthonous nutrients, (2) gravitational circulation and residence time of water in the system, and (3) vertical stability of the water column (cf. Stefansson \& Richards 1963, Malone 1977, Cloern et al. 1983, Pennock 1985, Peterson et al. 1985, Ward \& Twilley 1986). The long-term mean annual cycle of freshwater flow from the Susquehanna River is characterized by a spring maximum during March-April of $2.1 \times 10^{8} \mathrm{~m}^{3} \mathrm{~d}^{-1}$, and a summer minimum during August-September of $0.3 \times 10^{8} \mathrm{~m}^{3} \mathrm{~d}^{-1}$ (Schubel \& Pritchard 1986). River discharge was below average throughout 1985 and close to average in 1986 (Fig. 2). The 2 yr also differed in the duration and magnitude of the spring freshet. The 1985 freshet peaked during 12 March to 9 April with a mean of $1.6 \times 10^{8} \mathrm{~m}^{3} \mathrm{~d}^{-1}$ compared to the 1986 freshet which peaked during 11 


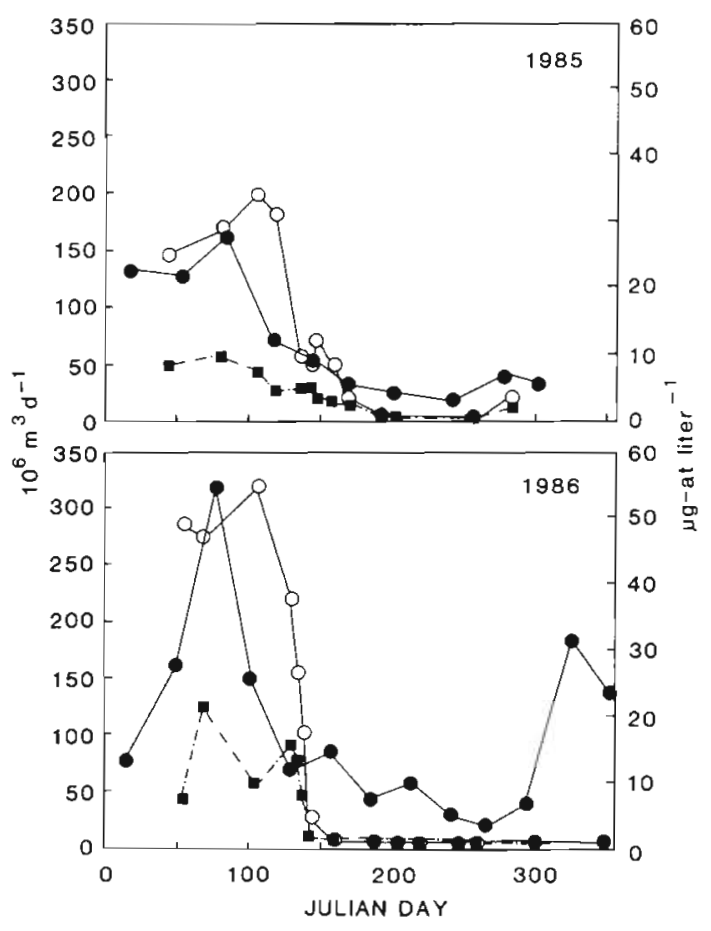

Fig. 2. Annual cycles of freshwater flow (•) of the Susquehanna River and mean nitrate concentration in surface (o) and bottom (-) water of the mesohaline reach of Chesapeake Bay; flow data provided by the U. S. Geological Survey

to 25 March with a mean of $3.2 \times 10^{8} \mathrm{~m}^{3} \mathrm{~d}^{-1}$ These variations in flow were reflected in the annual cycles of nitrate and salinity. Nitrate concentration was highest in the surface layer where annual maxima of 34 and $55 \mu \mathrm{g}$-at $\mathrm{l}^{-1}$ were observed in mid-April of 1985 and
1986, respectively. Downstream displacement of surface isohalines was also greater in 1986 than in 1985 and lagged peak freshwater flow by 20 to $30 \mathrm{~d}$ (Fig. 3). Given the resolution of our observations, the distributions of both nitrate and salinity indicate that the mesohaline reach of the Bay responded to variations in freshwater flow with a lag of about 1 mo.

\section{ANNUAL CYCLES OF CHLOROPHYLI, AND PHYTOPLANKTON PRODUCTIVITY}

Like nitrate, seasonal variation in the chlorophyll a (Chl) content of the water column of the main channel was characterized by a pronounced spring maximum (Fig. 4). The temporal sequence of events occurred 2 to 4 wk later in 1986 than in 1985. Following a transition period of rapid decline during late May, 1 to 2 small peaks developed during summer. The spring bloom peaked in mid-April 1985 compared to mid-May 1986 and declined to a minimum by late May and early June, respectively. Likewise, summer peaks greater than $125 \mathrm{mg} \mathrm{m}^{-2}$ developed in mid-June and in mid-July 1985, and in early August 1986. Comparison of euphotic zone and water column $\mathrm{Chl}$ shows that while the collapse of the spring bloom occurred over the entire water column, Chl below the euphotic zone accounted for most of the decline (Fig. 4). In contrast, summer peaks were mainly due to increases in the Chl content of the surface layer. Thus, most Chl was located in the bottom layer below the euphotic zone during the spring bloom and in the surface layer within the euphotic zone during summer.

Maximum Chl content of the water column during
Fig. 3. Seasonal variations in the distribution of surface salinity at channel stations along the main axis of the Bay

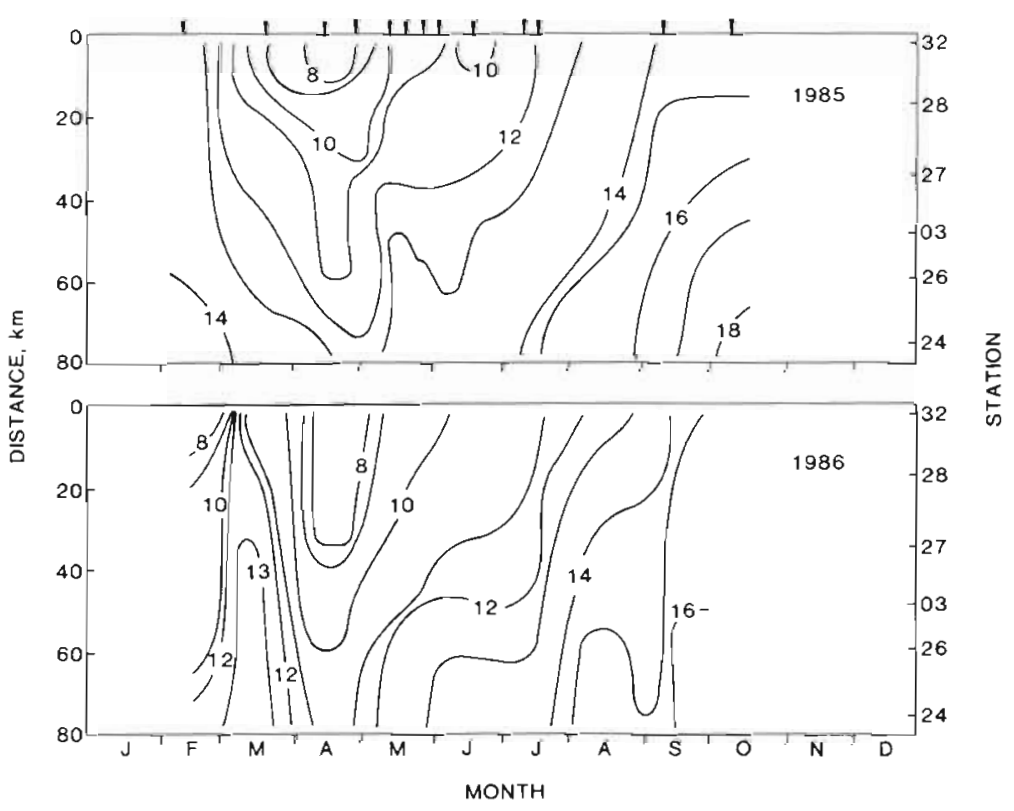




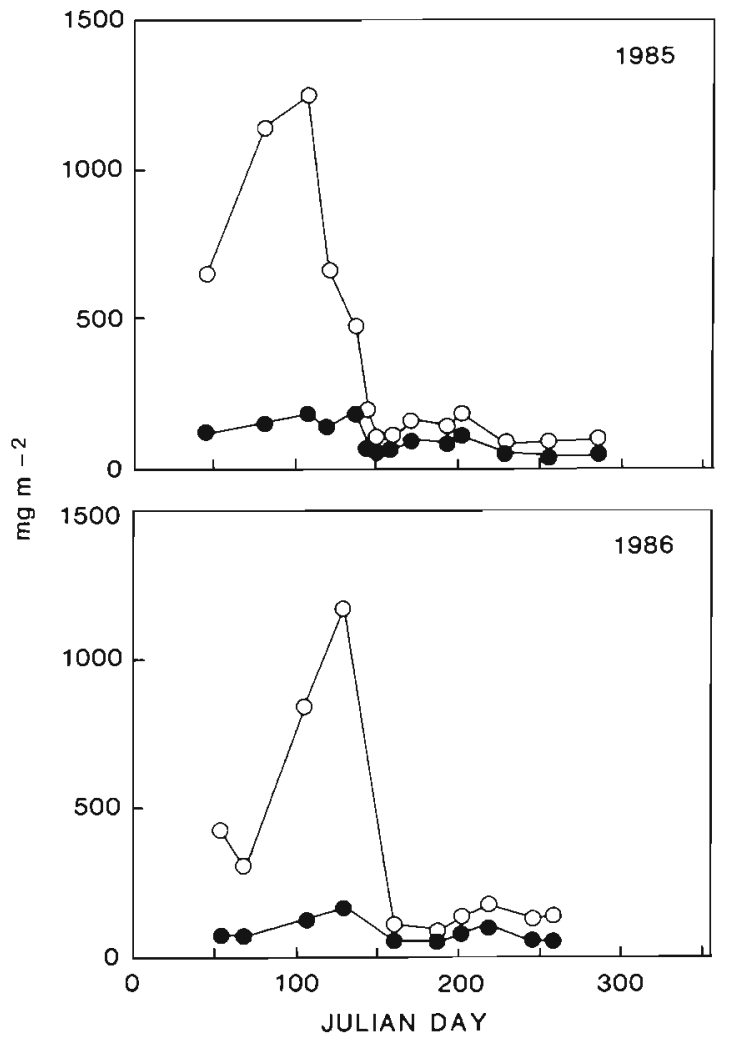

Fig. 4. Annual cycles of mean chlorophyll content of the water column (o) and euphotic zone (•)

spring exceeded $2000 \mathrm{mg} \mathrm{m}^{-2}$ and was centered near the $10 \%$ isohaline about $20 \mathrm{~km}$ downstream of the northernmost station during both years (Fig. 5). During 1985, the spring bloom peaked in mid-March at the southern end of the study area and progressed upstream to a peak in late April at the northern end of the study area (Fig. 5). A similar progression occurred during 1986 but began in mid-April and ended in midMay. Chl content of the euphotic zone, which was typically confined to the surface layer above the halocline, generally paralleled these variations with spring maxima greater than $200 \mathrm{mg} \mathrm{m}^{-2}$ and summer peaks greater than $50 \mathrm{mg} \mathrm{m}^{-2}$ (Fig. 6).

Lateral distributions normal to the main channel were documented most frequently along the Chop-Pax transect located in the central region of the study area. For comparison, we present only integral euphotic zone Chl since the euphotic zone typically reached the bottom at the shallow stations along the flanks of the main channel (Fig. 7). Chl content of the euphotic zone was similar to the annual cycle described for the channel station except during 1986 when mean Chl peaked in mid-April rather than in mid-May due to the earlier development of high $\mathrm{Chl}$ over the flanks and the later development of the spring bloom upstream of the Chop-Pax transect. Peaks in Chl were highest on the flanks and appeared to be associated with the development of high Chl over the channel during both spring and summer blooms. The spring bloom began to collapse in mid-May during both 1985 and 1986. Together, the distributions shown in Figs. 4 to 7 indicate a temporal sequence of seasonal events which characterized the entire mesohaline reach of the Bay.

The annual cycle of phytoplankton productivity was similar to that described by Flemer (1970) and Boynton et al. (1982) and was seasonally out of phase with the annual cycle of euphotic zone chlorophyll (Fig. 8). Productivity began to increase later in 1985 than in 1986 and did not exceed $1 \mathrm{~g} \mathrm{C} \mathrm{m}^{-2} \mathrm{~d}^{-1}$ until July 1985

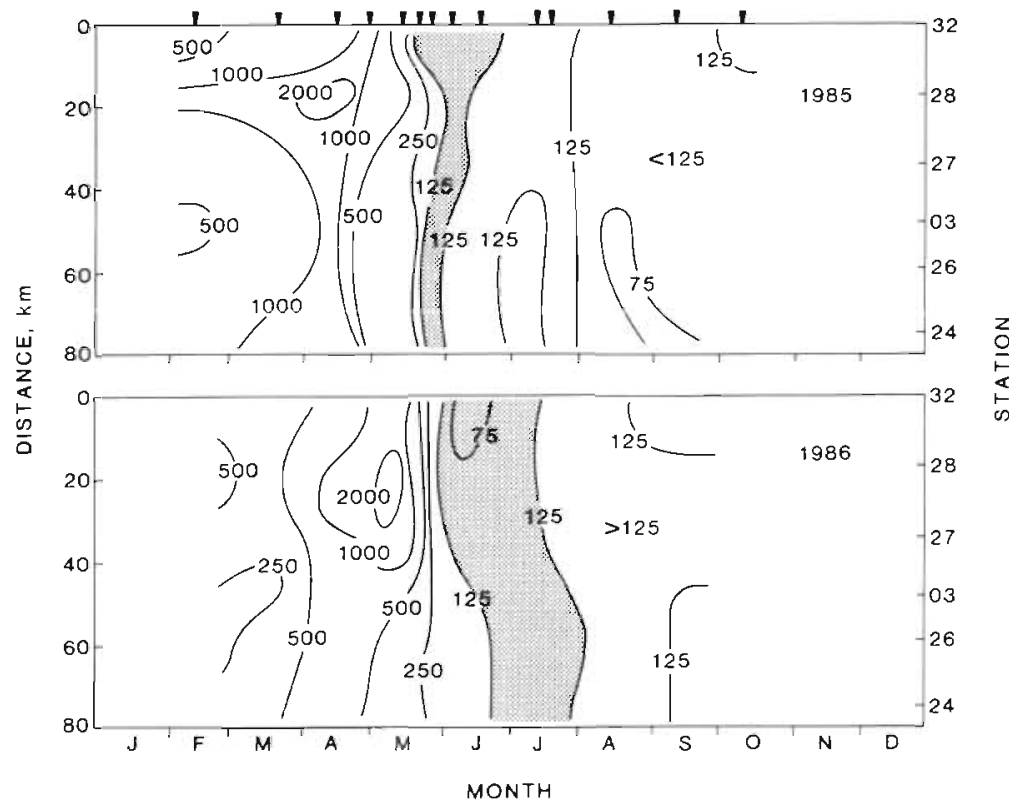

Fig. 5. Seasonal variations in the distribution of water column chlorophyll ( $\mathrm{mg} \mathrm{m}^{-2}$ ) at channel stations along the main axis of the Bay; timing of the chlorophyll minimum between the spring bloom and secondary summer peaks indicated by stippling 
Fig. 6. Seasonal variations in the distribution of euphotic zone chlorophyll ( $\mathrm{mg} \mathrm{m}^{-2}$ ) at channel stations along the main axis of the Bay

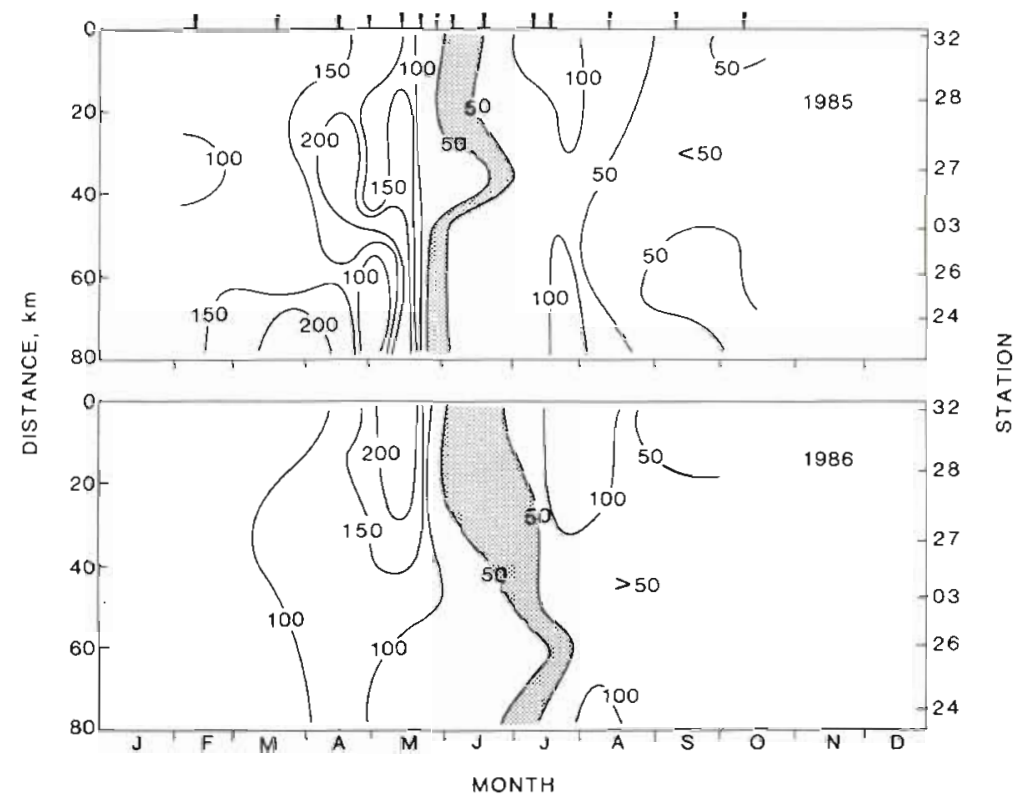

Fig. 7. Seasonal variations in the distribution of euphotic zone chlorophyll $\left(\mathrm{mg} \mathrm{m}^{-2}\right)$ at stations along the Chop-Pax transect normal to the main axis of the Bay

\section{DISCUSSION}

compared to April 1986. Timing and magnitude of maximum summer productivity also varied between years with a transect mean maximum of $4.2 \mathrm{~g} \mathrm{C} \mathrm{m}^{-2} \mathrm{~d}^{-1}$ in August 1985 compared to $2.1 \mathrm{~g} \mathrm{C} \mathrm{m}^{-2} \mathrm{~d}^{-1}$ in July 1986. Thus, phytoplankton productivity was lower during the spring Chl maximum and higher during the summer productivity maximum in 1985 than in 1986 (Fig. 8, Table 1). Annual production was calculated to be $550 \mathrm{~g}$ $\mathrm{C} \mathrm{m}^{-2}$ in 1985 , and $430 \mathrm{~g} \mathrm{C} \mathrm{m}^{-2}$ in 1986 - a difference which reflects higher summer productivity in 1985. Both estimates are in the range of values reported by Boynton et al. (1982) for 1972-1977. In contrast to spatial variations in phytoplankton along the salinity gradient of the Bay (Harding et al. 1986), variations in productivity between seasons and years were related to variations in Chl specific productivity (Table 1 ).

\section{Freshwater flow and phytoplankton biomass}

Timing and magnitude of the spring bloom in the mesohaline reach of the Bay appear to be related to the delivery of nitrate and to the concentrating effects of 2 layered estuarine circulation. The spring bloom was initiated as salinity began to decrease in response to the spring freshet in late March-early April and declined rapidly in late May as salinity increased (Figs. 3 and 5). Chl peaked earlier downstream than upstream in both years such that maximum $\mathrm{Chl}$ coincided with the salinity minimum in 1985 and lagged the salinity minimum in 1986, perhaps as a result of high spring flow in 1986 relative to 1985 (cf. Cloern et al. 1983, Pennock 1985). 

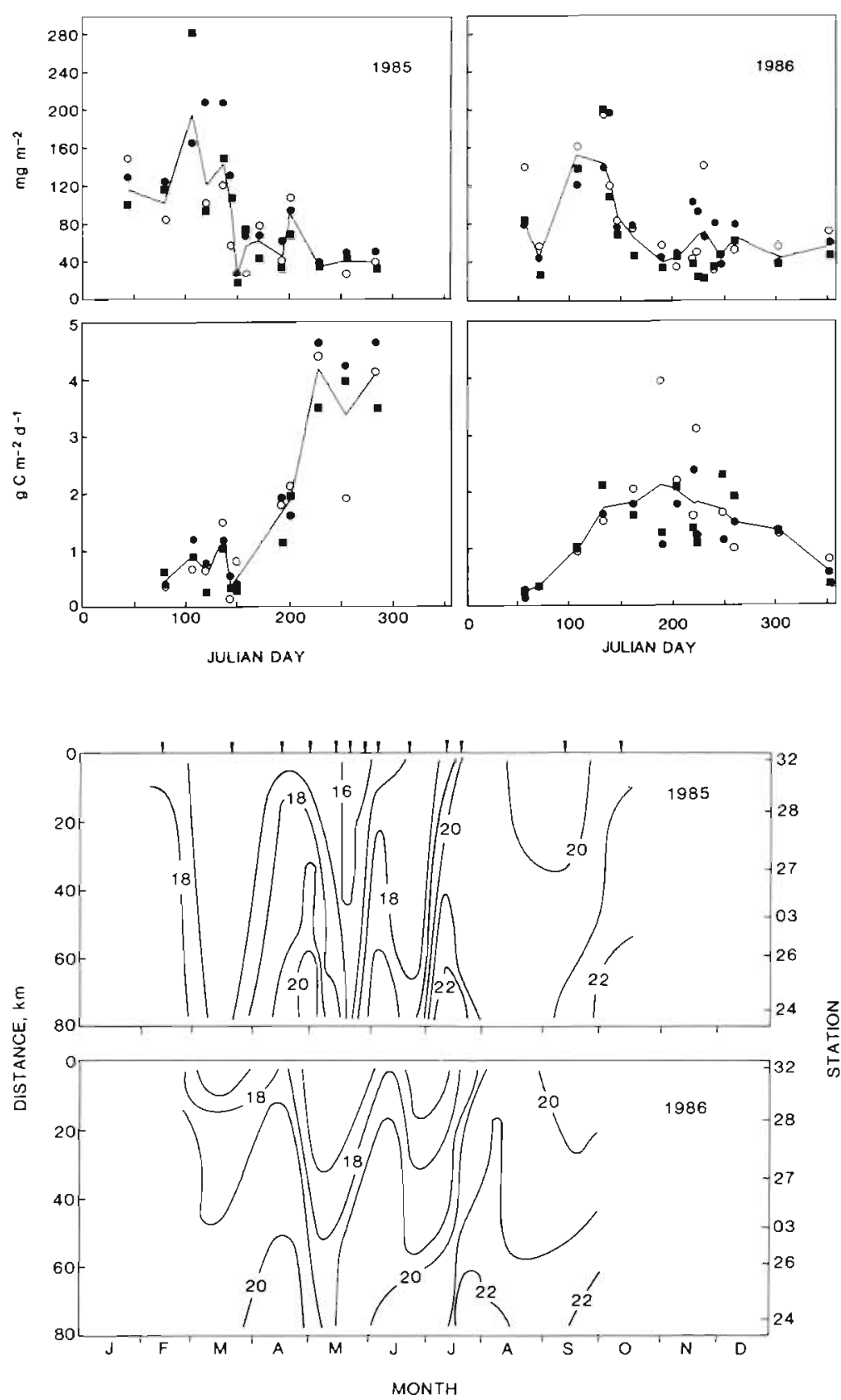

Fig. 8. Annual cycles of mean (solid line) euphotic zone chlorophyll $\left(\mathrm{mg} \mathrm{m}^{-2}\right)$ and phytoplankton productivity $\left(\mathrm{g} \mathrm{C} \mathrm{m}^{-2} \mathrm{~d}^{-1}\right)$ for the stations of the Chop-

Pax transect (Stn $010, \operatorname{Stn} 03 \bullet$, Stn 05 )
Fig. 9. Seasonal variations in the distribution of bottom salinity at channel stations along the main axis of the Bay
Given the high Chl content of the water column below the euphotic zone during the development of the spring bloom, this progression suggests that much of the accumulated Chl was advected into the region with the upstream flow of bottom water. Mass transport of Chl from downstream is indicated by the upstream displacement of isohalines during this period (Fig. 9). Chl content of the water column began to increase with the intrusion of high salinity bottom water In 1985, the bloom peaked during the early stages of this intrusion and began to collapse as the intrusion intensified. Minimum Chl following the bloom coincided with a second intrusion of high salinity water in late May In
1986, the bloom did not peak until salinity began to decrease following the high salinity intrusion and collapsed with the onset of the second high salinity intrusion. This suggests a greater downstream displacement of the high production zone in 1986 due to higher flow and, consequently, a longer lag between riverine nitrate input in the surface layer and subsequent upstream transport of $\mathrm{Chl}$ with bottom water This would explain the lag between the salinity minimum and the Chl maximum observed in 1986. The conceptual model most consistent with these observations involves nutrient uptake and biomass production in the surface layer during seaward transport, sedimentation of biomass 
Table 1. Time- and space-averaged chlorophyll (Chl, $\mathrm{mg} \mathrm{m}^{-2}$ ), phytoplankton productivity $\left(\mathrm{P}, \mathrm{mg} \mathrm{C} \mathrm{m}^{-2} \mathrm{~d}^{-1}\right), \mathrm{Chl}$-specific productivity $\left(P_{c h}, \operatorname{mg~C} \mathrm{mg} \mathrm{Chl} l^{-1} \mathrm{~d}^{-1}\right)$ carbon-specific growth rate $\left(\mu, \mathrm{d}^{-1}\right)$, dilution rate of the surface layer $\left(D, \mathrm{~d}^{-1}\right)$, and related parameters for the Chop-Pax transect $\left(\mathrm{Chl} / \mathrm{C}=\right.$ ratio of Chl to phytoplankton-carbon biomass by weight.) $\mathrm{S}_{\mathrm{b}}$ : bottom water salinity; $S_{s}$ : surface water salinity; $Q_{\mathrm{f}}$ : volume transport of freshwater, $10^{7} \mathrm{~m}^{3} \mathrm{~d}^{-1}$; $D O$ : dissolved oxygen content of the bottom layer, $\mathrm{g} \mathrm{m}^{-2}$ )

\begin{tabular}{|c|c|c|c|c|c|c|c|c|c|c|c|}
\hline Year & Month & Chl & $\mathrm{P}$ & $P_{\text {chl }}$ & $\mathrm{Chl} / \mathrm{C}^{\mathrm{a}}$ & $\mu^{\mathrm{b}}$ & $\mathrm{S}_{b}-\mathrm{S}_{\mathrm{s}}$ & $Q_{\mathbb{1}}$ & $D_{c}$ & $\mu / D$ & DO \\
\hline \multirow[t]{4}{*}{1985} & Feb-Apr & 126 & 440 & 3 & 0.033 & 0.12 & 5.9 & 11.5 & 0.07 & 2 & 78.3 \\
\hline & May-Jun & 74 & 925 & 12 & 0.025 & 0.31 & 4.5 & 5.2 & 0.03 & 10 & 19.1 \\
\hline & Jul-Aug & 48 & 4300 & 90 & 0.020 & 1.79 & 5.1 & 1.8 & 0.02 & 90 & 8.8 \\
\hline & Sep-Oct & 39 & 3600 & 92 & 0.007 & 0.61 & 4.3 & 2.8 & 0.02 & 30 & 14.0 \\
\hline \multirow[t]{4}{*}{1986} & Feb-Apr & 119 & 640 & 5 & 0.017 & 0.09 & 8.3 & 18.4 & 0.08 & 1 & 80.6 \\
\hline & May-Jun & 93 & 1760 & 19 & 0.014 & 0.27 & 5.3 & 7.1 & 0.04 & 7 & 21.9 \\
\hline & Jul-Aug & 52 & 2100 & 40 & 0.017 & 0.67 & 6.6 & 4.5 & 0.02 & 34 & 2.1 \\
\hline & Sep-Oct & 50 & 1540 & 31 & 0.020 & 0.62 & 5.3 & 3.0 & 0.04 & 16 & 21.6 \\
\hline \multicolumn{12}{|c|}{$\begin{array}{l}\text { a Calculated for each period as described by Chervin et al. (1981) } \\
\text { b } \mu=P_{c h l} \text { (Chl/C) } \\
\text { c } D=Q_{s} / V \text { where } Q_{s}=Q_{f}\left(S_{b} /\left[S_{b}-S_{s}\right]\right) ; V=\text { volume of the eupho }\end{array}$} \\
\hline
\end{tabular}

into the bottom layer, and upstream transport of biomass with the landward advection of bottom water.

Delay of the 1986 spring bloom may also reflect more rapid flushing of the surface layer in response to higher freshwater flow. Assuming conservation of salt on a monthly time scale and that chlorophyll specific productivity is a reasonable index of phytoplankton growth rate, the dilution rate of the surface layer and carbon specific growth rate were calculated as described by Malone (1977) and Malone et al. (1983). Carbon-specific growth rates varied from $0.1 \mathrm{~d}^{-1} \mathrm{du}-$ ring spring bloom, to $1.8 \mathrm{~d}^{-1}$ during peak summer productivity (Table 1). Comparison of these growth rates to the dilution rate of the euphotic zone by the non-tidal, seaward flow of surface water indicated that growth and dilution were in approximate balance during the 1986 spring bloom and that growth exceeded dilution by a factor of 2 during the 1985 spring bloom (Table 1). Thus, production within the study area was more important as a source of biomass in 1985 when river flow was low compared to 1986 when river flow was higher and mass transport of biomass from downstream was relatively more important.

High rates of growth relative to dilution suggest the possibility that phytoplankton production in terms of biomass yield could depend on the external supply of new nitrogen. To test this hypothesis, time and space weighted mean monthly Chl was compared to monthly averaged volume transport of freshwater from the Susquehanna River (Fig. 2). By lagging flow by 1 mo to account for the delayed response of the mesohaline reach of the Bay, freswater flow and $\mathrm{Chl}$ were significantly correlated $(p<0.001)$ with variations in flow accounting for $82 \%$ of the Chl variance. This relationship was not solely a consequence of the seasonal variation in $\mathrm{Chl}$ and flow as indicated by the correlation
Table 2. Coefficients of determination $\left(r^{2}\right)$ and least square regressions of particulate organic nitrogen $(\mathrm{PN}, \mu \mathrm{g})$ on chlorophyll $(\mathrm{Chl}, \mu \mathrm{g})(\mathrm{PN}=\mathrm{a} \mathrm{Chl}+\mathrm{b})$

\begin{tabular}{|c|c|c|c|c|c|}
\hline Year & Month & $n$ & $r^{2}$ & a (SE) & $\mathrm{b}(\mathrm{SE})$ \\
\hline $1984^{a}$ & Jul-Aug & 21 & 0.66 & $9.9(1.1)$ & $88(69)$ \\
\hline 1985 & $\begin{array}{c}\text { Feb-Apr } \\
\text { May-Jun } \\
\text { Jul-Oct }\end{array}$ & $\begin{array}{l}18 \\
32 \\
32\end{array}$ & $\begin{array}{l}0.64 \\
0.57 \\
0.56\end{array}$ & $\begin{array}{l}5.5(1.0) \\
6.1(1.0) \\
9.1(1.5)\end{array}$ & $\begin{array}{r}64(54) \\
76(50) \\
105(84)\end{array}$ \\
\hline 1986 & $\begin{array}{c}\text { Feb-Apr } \\
\text { May-Jun } \\
\text { Jul-Oct }\end{array}$ & $\begin{array}{l}20 \\
20 \\
56\end{array}$ & $\begin{array}{l}0.64 \\
0.72 \\
0.73\end{array}$ & $\begin{array}{r}8.4(1.5) \\
6.2(0.9) \\
10.0(0.7)\end{array}$ & $\begin{array}{l}82(51) \\
79(65) \\
76(48)\end{array}$ \\
\hline
\end{tabular}

between Chl and flow rate when the high flow months of spring were excluded ( $r=0.75, n=14, p<0.01$ ). For a quantitative comparison of nitrate input ( $Q-N)$ and total phytoplankton biomass in the study area, biomass as nitrogen ( $\mathrm{Ph}-\mathrm{N})$ was estimated from the product of monthly mean Chl, N/Chl ratios (Table 2), and a surface area of $1.1 \times 10^{9} \mathrm{~m}^{2}$. Note that the $\mathrm{N} / \mathrm{Chl}$ ratio estimated for the 1986 spring bloom period is higher by a factor of 1.5 than during the same period in 1985. Freshwater flow and nitrate concentration were higher by a similar factor (1.6). Thus, while $\mathrm{Chl}$ levels did not differ substantially between years, nitrogen-biomass varied in proportion to freshwater flow and nitrate concentration. Nitrate input from the Susquehanna was assumed to be the sole source of allochthonous nitrogen and was estimated as the product of freshwater volume transport and nitrate concentration of the freshwater end member. The latter was estimated to be $100 \mu \mathrm{g}$-at $\mathrm{l}^{-1}$ based on the conservative mixing line for flows greater than $10^{8} \mathrm{~m}^{3} \mathrm{~d}^{-1}$ (least-square, linear regression of nitrate on salinity: $\mathrm{NO}_{3}=112-6.5 \mathrm{~S}, r^{2}=$ 

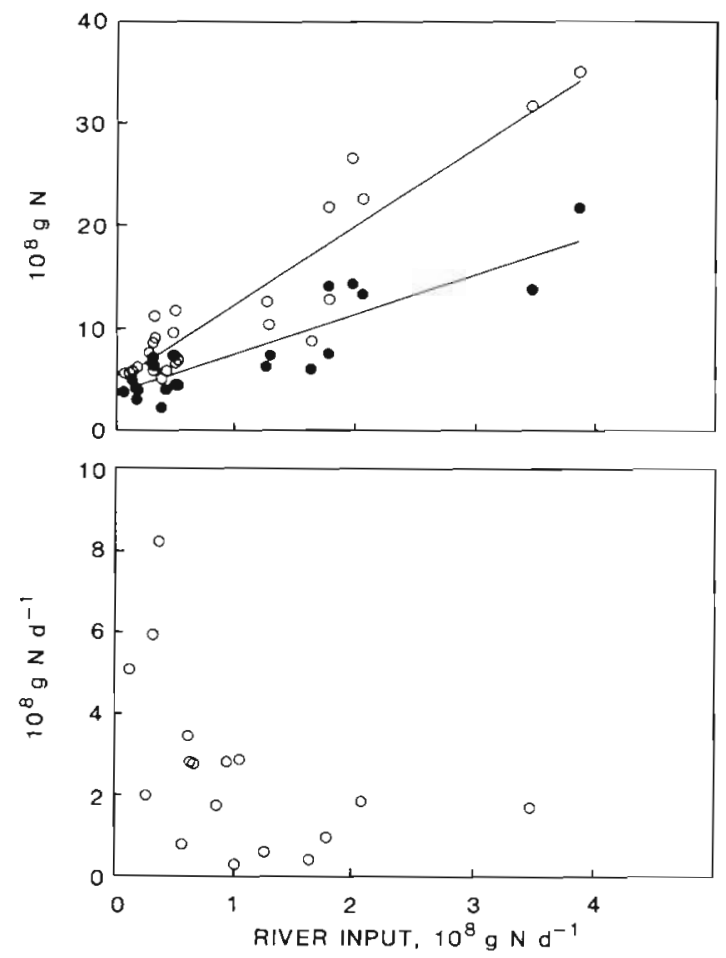

Fig. 10. Relationships between monthly mean phytoplankton biomass $\left(10^{8} \mathrm{~g} \mathrm{~N}\right.$; euphotic zone $\bullet$, water column o), nitrogen assimilation $\left(10^{8} \mathrm{~g} \mathrm{~N} \mathrm{~d}^{-1}\right)$ and riverine nitrogen input for the mesohaline reach of the Bay between $38^{\circ} 59^{\prime} \mathrm{N}$ and $38^{\circ} 20^{\prime} \mathrm{N}$ $\left(\right.$ area $\left.=1.078 \times 10^{9} \mathrm{~m}^{2}\right)$; includes data from 1984 (Malone et al. 1986)

0.99 ) and $50 \mu \mathrm{g}$-at $\mathrm{l}^{-1}$ for lower flows (Smullen et al. 1982). These are obviously rough approximations, but will suffice for the purposes of these calculations. Biomass was estimated for the euphotic zone and for the entire water column, both of which were found to be significantly correlated $(p<0.001)$ with nitrate supply (Fig. 10) by the least square regressions:

(1) (Water Column):

$$
\mathrm{Ph}-\mathrm{N}=4.6+7.7(\mathrm{Q}-\mathrm{N}) \quad\left(r^{2}=0.86, n=24\right)
$$

(2) (Euphotic Zone):

$$
\mathrm{Ph}-\mathrm{N}=3.5+3.9(\mathrm{Q}-\mathrm{N}) \quad\left(r^{2}=0.78, n=24\right)
$$

As indicated by the slopes of these regressions, a unit increase in nitrate input resulted, on average, in a 4 fold increase in phytoplankton biomass in the euphotic zone and an 8 fold increase in the water column as a whole. While these calculations are subject to large errors, they are indicative of the effects of 2-layered estuarine circulation and nutrient recycling on the accumulation of phytoplankton biomass within the mesohaline reach of the Bay. As discussed above, the development of the spring $\mathrm{Chl}$ maximum appears to be due to sedimentation and accumulation of Chl within the study area and to the advection of Chl into the study area with bottom water from downstream. Varia- tions in the magnitude of the spring biomass maximum were related to the amount of nitrate delivered to the system during the spring freshet. Our results indicate that the lag between the spring freshet and the magnitude of the spring accumulation of phytoplankton biomass increase in relation to the volume transport of freshwater during late winter-early spring. Evidence is discussed below which suggests that the seasonal and vertical separation of phytoplankton production in the surface layer and benthic ammonium regeneration from that production allow for the high productivity characteristic of summer.

\section{Nitrogen cycling and phytoplankłon productivity}

Regeneration, the major source of ammonium in the Bay, supports on the order of 60 to $70 \%$ of annual phytoplankton production (Flemer et al. 1985). For nutrient regeneration to have such an effect, the production and decomposition of organic matter must be separated in time on scales which are long relative to phytoplankton generation times. Most regeneration on these timescales appears to occur in the benthos where ammonium regeneration rate varies seasonally with a summer maximum and a winter minimum (Kemp \& Boynton 1981, Smullen et al. 1982, Boynton \& Kemp 1985). Experimental results summarized by Nixon \& Pilson (1983) indicate that benthic rates of ammonium regeneration per unit of organic nitrogen input are on the order of 100 times slower than regeneration rates in the water column. The inverse relationship between phytoplankton productivity and nitrate transport into the Bay (Fig. 10) may reflect the importance of ammonium regeneration and the seasonal lag between nitrogen input and regeneration as indicated by annual cycles of ammonium concentration (Fig. 11). In contrast to nitrate which exhibited a spring maximum in the surface layer, ammonium exhibited a summer maximum in the bottom layer Bottom-water ammonium began to increase following the spring $\mathrm{Chl}$ maximum, and peaksin concentration of 20 to $40 \mu \mathrm{g}$-at $\mathrm{l}^{-1}$ were observed throughout the summer. Decreases in ammonium concentration during summer appeared to be related to intrusions of high salinity bottom water in that upstream displacements of isohalines coincided with decreases in ammonium concentration (Fig. 9). The ammonium content of bottom water at the time of the peaks varied from $5.6 \mathrm{~g} \mathrm{~N} \mathrm{~m}^{-2}$ in 1985 to $2.8 \mathrm{~g} \mathrm{~N} \mathrm{~m}^{-2}$ in 1986. This compares to phytoplankton biomass maxima of 1.8 to $2.9 \mathrm{~g} \mathrm{~N} \mathrm{~m}^{-2}$ during spring of 1985 and 1986 , respectively. Thus, the spring accumulation of phytoplankton biomass had the potential of providing about 30 and $100 \%$ of the ammonium which reappeared in the water column during the summers of 1985 and 1986 . respectively 
light and temperature as parameters of phytoplankton productivity as Harding et al. (1986) have shown for Chesapeake Bay. For example, chlorophyll-specific productivity $\left(\mathrm{P}_{\mathrm{chl}}, \mathrm{mg} \mathrm{C} \mathrm{mg} \mathrm{Chl} \mathrm{C}^{-1} \mathrm{~d}^{-1}\right.$ ) during 1987 was significantly correlated $\left(\mathrm{R}^{2}=0.54, p<0.001\right)$ with incident, photosynthetically active radiation (I, $\mathrm{E} \mathrm{\textrm {m } ^ { - 2 }}$ $\mathrm{d}^{-1}$ ) and temperature $\left(\mathrm{T},{ }^{\circ} \mathrm{C}\right)$ by the (Type II) multiple regression:

$$
P_{\text {chl }}=-55+2.0 \mathrm{I}+2.3 \mathrm{~T}
$$

Table 4. Interannual variations in mean productivity $(\mathrm{P}, \mathrm{mg} \mathrm{C}$ $\mathrm{m}^{-2} \mathrm{~d}^{-1}$ ), chlorophyll content of the euphotic zone (Chl, $\mathrm{mg}$ $\left.\mathrm{m}^{-2}\right)$, chlorophyll-specific productivity $\left(\mathrm{P}_{\mathrm{Chl}}, \mathrm{mg} \mathrm{C} \mathrm{mg} \mathrm{Chl}{ }^{-1}\right.$ $\mathrm{d}^{-1}$, and vertical salt stratification for July-August.

\begin{tabular}{|lcccc|}
\hline Year & $P$ & Chl & $P_{\text {chl }}$ & $S_{b}-S_{s}$ \\
\hline $1984^{\mathrm{a}}$ & 1840 & 74 & 25 & 9.3 \\
1985 & 4300 & 48 & 90 & 5.1 \\
1986 & 2100 & 52 & 40 & 6.6 \\
$1987^{\mathrm{b}}$ & 4425 & 59 & 75 & 5.3 \\
a Data from Malone et al. $(1986)$ & & \\
b Malone unpubl. & & \\
\hline
\end{tabular}

Incident PAR and temperature were of nearly equal importance as indicated by the partial correlation coefficients $(0.34$ and 0.27 for PAR and temperature, respectively). However, as reported by Boynton et al. (1982), large interannual variations occur in the magnitude of the summer productivity maximum which are related to variations in $\mathrm{P}_{c h l}$ (Table 4). These variations were correlated ( $r=0.96, n=4)$ with vertical salinity stratification (bottom salinity, $\mathrm{S}_{\mathrm{b}}-$ surface salinity, $\mathrm{S}_{\mathrm{s}}$ ) by the (Type II) regression:

$$
\ln \mathrm{P}_{\mathrm{chl}}=5.85-0.292\left(\mathrm{~S}_{\mathrm{b}}-\mathrm{S}_{\mathrm{s}}\right) \quad(r=0.96)
$$

This, and the results of nutrient enrichment studies which indicate that phytoplankton growth is likely to be nitrogen-limited during summer (D'Elia et al. 1986), support the hypothesis that the magnitude of the summer productivity maximum is a function of physical processes which regulate the recycling of ammonium from subpycnocline depths into the euphotic zone. As described by Malone et al. (1986), lateral 'tilting' of the pycnocline may be particularly important in this regard.

Comparison of these results with those for the coastal plume of the Hudson River illustrate the effects of seasonally pulsed inputs of new and recycled nitrogen (Table 5). Most new nitrogen input to the lower Hudson estuary is exported to the coastal plume where it is rapidly taken up by phytoplankton over an area which is roughly equivalent to the area of high uptake in Chesapeake Bay (Malone 1982b). The annual cycle of water column Chl in the plume is similar to that of the Bay in that maximum Chl occurs during FebruaryApril. However, the spring bloom in Chesapeake Bay is 5 times greater than that of the Hudson plume on average. In contrast, the annual cycles of productivity exhibit similar maxima but differ in timing with the productivity maximum of the plume occurring during early spring 5 to 6 mo prior to the productivity maximum of the Bay. These differences appear to be related to patterns of nutrient input and recycling and to the capacity to retain and concentrate biomass. New nitrogen supply to the Hudson plume is mainly derived from sewage and exhibits little seasonal variation relative to input to the Bay which is seasonally pulsed due to the large fraction of nitrogen derived from fertilizers (Malone 1982b, Smullen et al. 1982). High Chl in the Bay during February-April relative to other seasons and to the Hudson plume in general most likely reflects the pulsed nature of nitrogen input and the concentrating effects of estuarine circulation as discussed above. Regeneration and recycling of nitrogen assimilated during spring then supports the development of the summer productivity maximum of the Bay. As a consequence, a unit input of nitrogen to the mesohaline reach of the Bay supports 5 times more Chl during spring and 5 times more productivity during summer than in the plume (Table 5).

Table 5. Seasonal comparison of phytoplankton responses to nitrogen supply in the mesohaline reach of Chesapeake Bay and the

\begin{tabular}{|c|c|c|c|c|c|}
\hline Variable & System & Feb-Apr & May-Jun & Jul-Aug & Sep-Oct \\
\hline \multirow{2}{*}{$\mathrm{N}$-input $\left(10^{6} \mathrm{~g} \mathrm{~d}^{-1}\right)$} & Chesapeake & 181 & 116 & 40 & 22 \\
\hline & Hudson & 180 & 155 & 130 & 120 \\
\hline \multirow[t]{2}{*}{$\mathrm{Chl}\left(\mathrm{mg} \mathrm{m}^{-2}\right)$} & Chesapeake & 723 & 306 & 132 & 107 \\
\hline & Hudson & 147 & 76 & 60 & 88 \\
\hline \multirow[t]{2}{*}{$P\left(m g m^{-2} d^{-1}\right)$} & Chesapeake & 480 & 1224 & 2824 & 2570 \\
\hline & Hudson & 2833 & 2362 & 1724 & 1240 \\
\hline \multirow[t]{2}{*}{$\mathrm{Chl} / \mathrm{N}$-input } & Chesapeake & 4.0 & 2.6 & 3.3 & 4.9 \\
\hline & Hudson & 0.8 & 0.5 & 0.5 & 0.7 \\
\hline \multirow[t]{2}{*}{ P/N-input } & Chesapeake & 2.6 & 10.6 & 71.0 & 116.8 \\
\hline & Hudson & 15.7 & 15.2 & 13.3 & 10.3 \\
\hline
\end{tabular}
coastal plume of the Hudson River 


\section{Phytoplankton production and summer oxygen depletion}

The seasonal lag between the spring Chl maximum and summer regeneration provides a mechanism not
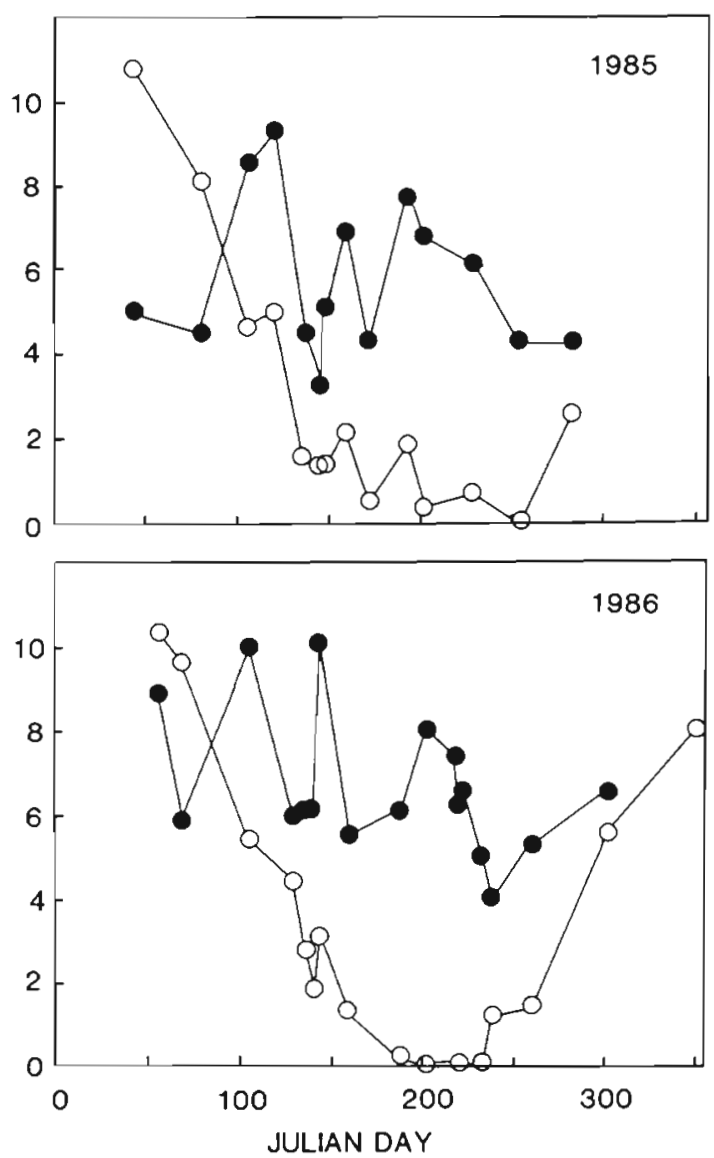

Fig. 12. Annual cycle of dissolved oxygen in bottom water $(0$, $\mathrm{ppm})$ and vertical salinity stratification $\left(\bullet, \mathrm{S}_{\mathrm{b}}-\mathrm{S}_{\mathrm{s}}\right.$ where $\mathrm{S}_{\mathrm{b}}=$ bottom water salinity; $S_{s}=$ surface water salinity)

only for enhancing summer productivity but also for seasonal oxygen depletion of bottom water. The concentration of dissolved oxygen (DO) in bottom water declined throughout the spring bloom and fell below $2 \mathrm{ppm}$ as the bloom collapsed (Fig. 12). Bottom water was anoxic throughout most of July and August, 1986 , but anoxia did not occur in 1985 until late August. The decline in bottom water DO during spring was significantly correlated $(p<0.01)$ with temperature by the regression equations:

(1) (1985) $\mathrm{DO}=10.14-0.49(\mathrm{~T}) \quad\left(r^{2}=0.88, n=7\right)$

(2) (1986) $\mathrm{DO}=10.71-0.47(\mathrm{~T}) \quad\left(r^{2}=0.96, n=6\right)$

It is noteworthy that, despite large differences in vertical stratification (Fig. 12, Table 1) and freshwater flow (Fig. 2), the rate of DO depletion with increasing tem- perature was similar in 1985 and 1986. Mean Chl content of the water column at the peak of the spring bloom was in the range of 1200 to $1300 \mathrm{mg} \mathrm{m}^{-2}$ during both years. Biomass as nitrogen was apparently greater in 1986 as indicated by higher $\mathrm{N} / \mathrm{Chl}$ ratio (Tables 2 and 3). Likewise, biomass as carbon, calculated from $\mathrm{C} / \mathrm{Chl}$ (Table 1), peaked at $72 \mathrm{~g} \mathrm{~m}^{-2}$ in 1986 compared to $39 \mathrm{~g} \mathrm{~m}^{-2}$ in 1985. Assuming stoichiometry between carbon, oxygen and carbon dioxide, these concentrations correspond to aerobic oxygen demands of about 100 to $200 \mathrm{~g} \mathrm{O}_{2} \mathrm{~m}^{-2}$, more than sufficient to account for oxygen depletion given reasonable rates of vertical eddy diffusion (Officer et al. 1984)

The occurrence and extent of summer anoxia appeared to be related to both vertical stratification during summer and to nitrate loading during the spring freshet. On time scales of days to weeks, increases in DO coincided with or occurred soon after decreases in vertical stratification once bottom water DO fell below about $2 \mathrm{ppm}$ (Fig. 12). This implies a response to increased vertical mixing or lateral oscillations of the pycnocline (Malone et al. 1986). Interannually, mean bottom water DO during July-August was related to differences in stratification between summers (Table 1) and to differences in nitrate loading during the previous spring (Table 3). Summer productivity did not seem to be a major factor since productivity and DO were inversely related, a finding which is consistent with the conclusion that summer productivity depends on the physically driven recycling of ammonium into the euphotic zone. Contrary to the notion that oxygen demand during any given year is a function of the decomposition of organic detritus formed during the previous year and that summer anoxia is the result of increased stratification during spring (Officer et al. 1984), our results indicate that DO depletion of bottom water during spring was primarily a consequence of temperature-dependent metabolism of recently produced organic matter and is relatively insensitive to variations in vertical stratification over a wide range of salinity gradients. The occurrence and extent of anoxia and the frequency of reoxygenation events during summer appeared to be determined by the magnitude of the spring bloom and the strength and variability of vertical stratification during summer.

\section{CONCLUSIONS}

The annual cycle of phytoplankton productivity in the mesohaline reach of Chesapeake Bay is governed by incident PAR, temperature, and nitrogen recycling. Seasonal and interannual variations in phytoplankton biomass occur in response to variations in fresh water flow and associated variations in nitrate flux. Fresh 
water flow and nitrate input during the spring freshet govern the timing and magnitude of the spring biomass maximum which determine the amount of nitrogen available for recycling during subsequent summer months. The occurrence of a summer productivity maximum and interannual variations in the magnitude of this maximum reflect the effects of vertical stratification on the return flux of ammonium from the benthos to the euphotic zone. Given the broad spectrum of estuaries which have annual cycles of productivity characterized by a summer maximum (Boynton et al. 1982), such a seasonal coupling between spring nutrient input, benthic regeneration and summer productivity may be a general phenomenon in mid-latitude, partially stratified estuaries.

Two scales of interaction appear to characterize the production of organic matter by phytoplankton in the surface layer and subsequent nutrient regeneration and oxygen depletion below the euphotic zone. Seasonally, sedimentation of the spring bloom fuels the regeneration of nutrients and maintenance of anoxia during summer. On a shorter time scale (days-weeks), sedimentation of phytoplankton production during spring provides the organic substrates for temperaturedependent oxygen consumption which causes the rapid decline in DO during spring. While vertical stratification is a necessary condition for this decline, bottom water DO did not appear to be sensitive to variations in stratification during the spring decline. During summer, phytoplankton productivity and grazing are closely coupled and sedimentation of fecal material and pseudofeces produced by grazing activity supplement the spring supply of phytoplankton (Malone et al. 1986). The effects of vertical stratification are most pronounced during summer when vertical fluxes of ammonium and oxygen respectively limit phytoplankton productivity in the surface layer and oxygenation of bottom water. Thus, the primary determinants of summer phytoplankton productivity in the surface layer and anoxia in the bottom layer are the magnitude of the spring freshet and the strength and variability of the summer halocline.

Finally, it is evident that the relationship between new and regenerated production proposed for the open ocean (Dugdale \& Goering 1967, Eppley \& Peterson 1979 ) is more complex in estuarine systems (Kemp \& Boynton 1974). In the open ocean, phytoplankton production and nutrient regeneration are either closely coupled in time and space (ammonium assimilation = regenerated production) or separated by very large time and space scales (nitrate assimilation = new production). In estuaries, coupling between production and regeneration occurs over a continuum of time and space scales so that the distinction between new and regenerated production is not as clear and cannot be made based on such factors as the oxidation state of the nutrient element in question. Perhaps the distinction between new and regenerated nutrients should be based on the scales by which primary production and nutrient regeneration are separated in time and space relative to the generation times of the primary producers. Thus, ammonium in Chesapeake Bay is regenerated nitrogen if it is produced and consumed in the euphotic zone but new nitrogen if it is produced below the euphotic zone where it must be returned into the euphotic zone for uptake to occur.

Acknowledgements. Support for this research was provided by the University of Maryland Sea Grant College and by Horn Point Environmental Laboratories of the University of Maryland Center for Environmental and Estuarine Studies. We thank W. M. Kemp and W. R. Boynton for valuable discussions leading to the preparation of this manuscript.

\section{LITERATURE CITED}

Biggs, R. B., Flemer, D. A. (1972). The flux of particulate carbon in an estuary. Mar. Biol. 12: 11-17

Boynton, W. R., Kemp, W. M. (1985). Nutrient regeneration and oxygen consumption by sediments along an estuarine salinity gradient. Mar. Ecol. Prog. Ser. 23: 45-55

Boynton, W. R., Kemp, W. M., Keefe, C. W. (1982). A comparative analysis of nutrients and other factors influencing estuarine phytoplankton production. In: Kennedy, V.S. (ed.) Estuarine comparisons. Academic Press, New York, p. 69-90

Cadée, G. C. (1986). Increased phytoplankton primary production in the Marsdiep Area (Western Dutch Wadden Sea). Netherlands J. Sea Res. 20: 285-290

Carpenter, J. H., Pritchard, D. W. Whaley, R. C. (1969). Observations of eutrophication and nutrient cycles in some coastal plain estuaries. In: Eutrophication: causes, consequences and correctives. Proceedings of Symp. Natl. Acad. Sci. Publ. 1700, Wash., D. C., p. 210-221

Chervin, M. B., Malone, T C, Neale, P. J. (1981). Interactions between suspended organic matter and copepod grazing in the plume of the Hudson River. Estuar. coast. Mar. Sci. 13: 169-184

Cloern, J. E., Alpine, A. E., Cole B. E., Wong, R. L., Arthur, J. F., Ball, M. D. (1983). River discharge controls phytoplankton dynamics in the northern San Francisco Bay estuary. Estuar. Coast. Shelf Sci. 16: 415-429

Cole, B. E., Cloern, J. E. (1984). Significance of biomass and light availability to phytoplankton productivity in San Francisco Bay. Mar. Ecol. Prog. Ser. 17: 15-24

D'Elia, C. F., Sanders, J. G., Boynton, W. R. (1986). Nutrient enrichment studies in a coastal plain estuary: phytoplankton growth in large-scale, continuous cultures. Can. J. Fish. Aquat. Sci. 43: 397-406

Dugdaie, R. C., Goering, J. J. (1967). Uptake of new and regenerated forms of nitrogen in primary productivity. Limnol. Oceanogr. 12:196-206

Eppley, R. W., Peterson, B. J. (1979). Particulate organic matter flux and planktonic new production in the deep ocean. Nature, Lond. 282: 677-680

Fisher, T R., Harding, L. W., Stanley, D. W., Ward, L. G. (in press). Phytoplankton, nutrients, and turbidity in the Chesapeake, Delaware, and Hudson estuaries. Estuar. Coast. Shelf Sci. 
Flemer, D. A. (1970). Primary production in Chesapeake Bay. Chesapeake Sci. 11: 117-129

Flemer, D. A., Boynton, W. R., D'Elia, C. F., Kemp, W M. Nichols, M., Orth, R. J., Smullen, J. T., Taft, J., Wetzel, R. L. (1985). The Chesapeake Bay Program: a summary of scientific research to address management needs for Chesapeake Bay. In: Chao, N. L., Kirby-Snith, W (eds.) Proc. Intern. Symp. on utilization of coastal ecosystems: planning, pollution and productivity. Editora da Furg, Rio Grande, Brasıl, p. 399-438

Flint, R. W., Powell, G. L., Kalke, R. D. (1986). Ecological effects from the balance between new and recycled nitrogen in Texas coastal waters. Estuaries 9: 284-294

Harding, L. W., Meeson, B. W., Fisher, T R. (1986). Phytoplankton production in two east coast estuaries: photosynthesis-light functions and patterns of carbon assimilation in Chesapeake and Delaware Bays. Estuar Coast. Shelf Sci. 23: 773-806

Kemp, W M., Boynton, W. R. (1981). External and internal factors regulating metabolic rates of an estuarine benthic community. Oecologia 51:19-27

Kemp, W. M., Boynton, W. R. (1984). Spatial and temporal coupling of nutrient inputs to estuarine primary production: the role of particulate transport and decomposition. Bull. mar. Sci. 35: 242-247

Ketchum, B. H. (1967). Phytoplankton nutrients in estuaries. In: Lauff, G. H. (ed.) Estuaries AAAS Publ. No. 83, Washington, D. C., p. 329-335

Malone, T C. (1977). Environmental regulation of phytoplankton productivity in the lower Hudson Estuary. Estuar coast. Mar. Sci. 5: 157-171

Malone, T. C. (1982a). Phytoplankton photosynthesis and carbonspecific growth: light-saturated rates in a nutrient-rich environment. Limnol. Oceanogr 27: 226-235

Malone, T C. (1982b). Factors influencing the fate of sewagederived nutrients in the lower Hudson Estuary and New York Bight. In: Mayer, G. F. (ed.) Ecological stress and the New York Bight: science and management. Estuar. Res. Fed., Columbia, S. C., p. 389-400

Malone, T. C., Chervin, M. B. (1979). The production and fate of phytoplankton size fractions in the plume of the Hudson River, New York Bight. Limnol. Oceanogr. 24: 683-696

Malone, T C., Falkowski, P. G., Hopkins, T S., Rowe, G. T., Whitledge, T E. (1983). Mesoscale response of diatom populations to a wind event in the plume of the Hudson River. Deep Sea Res. 30: 149-170

Malone, T C., Kemp, W. M., Ducklow, H. W., Boynton, W. R., Tuttle, J. H., Jonas, R. B. (1986). Lateral variation in the production and fate of phytoplankton in a partially stratified estuary. Mar, Ecol. Prog. Ser. 32: 149-160

McCarthy, J. J., Taylor, W R., Taft, J. L. (1977). Nitrogenous nutrition of the plankton in the Chesapeake Bay. 1. Nutrient availability and phytoplankton preferences. Limnol. Oceanogr. 22: 996-1011

McCarthy, J. J., Taylor, W. R., Loftus, M. E. (1974). Significance of nanoplankton in the Chesapeake Bay estuary and problems associated with the measurement of nanoplankton productivity. Mar. Biol. 24: 7-16

Nixon, S. W. (1981). Remineralization and nutrient cycling in coastal marine ecosystems. In: Neilson, B. J., Cronin, L. E. (eds.) Estuaries and nutrients. Humana Press, Clifton, New Jersey, p. 111-138

Nixon, S. W. (1987). Remineralization and nutrient cycling in coastal marine ecosystems. In: Neilson, R. J., Cronin, L. E. (eds.) Estuaries and nutrients. Humana Press, N. Y., p. $111-138$

Nixon, S. W (1987). Chesapeake Bay nutrient budgets, a reasssessment. Biogeochem. 4: 77-90

Nixon, S. W., Pilson, M. G. (1983). Nitrogen in estuarine and coastal marine ecosystems. In: Carpenter, E. J., Capone, D. G. (eds.) Nitrogen in the marine environment. Academic Press, New York, p. 565-648

Officer, C. B., Biggs, R. B., Taft, J. L., Cronin, L. E., Tyler, M., Boynton, W. R. (1984). Chesapeake Bay anoxia: origin, development, and significance. Science 223: 22-27

Pennock, J. R. (1985). Chlorophyll distributions in the Delaware estuary: regulation by light-limitation. Estuar. Coast. Shelf Sci. 21: 711-725

Peterson, D. H., Smith, R. E., Hager, S. W., Harmon, D. D., Herndon, R. E., Schemel, L. E. (1985). Interannual variability in dissolved inorganic nutrients in northern San Francisco Bay estuary. Hydrobiologia 129: 37-58

Platt, T., Harrison, W. G. (1985). Biogenic fluxes of carbon and oxygen in the ocean. Nature, Lond. 318: 55-58

Redfield, A. C. (1955). The hydrography of the Gulf of Venezuela. Deep-Sea Res. 2 (Suppl.): 115-133

Schubel, J. R., Pritchard, D. W. (1986). Responses of upper Chesapeake Bay to variations in discharge of the Susquehanna River. Estuaries 9: 236-249

Smullen, J. T., Taft, J. L., Macknis, J. (1982). Nutrient and sediment loads to the tidal Chesapeake Bay system. In: U. S. EPA, Chesapeake Bay technical studies: a synthesis. Washington, D. C., p. 147-262

Stefansson, U., Richards, F. A. (1963). Processes contributing to the nutrient distribution off the Columbia River and Strait of Juan de Fuca. Limnol. Oceanogr. 8: 394-410

Taft, J. L., Elliot, A. J., Taylor, W. R. (1978). Box model analysis of Chesapeake Bay Ammonium and nitrate fluxes. In: Wiley, M. L. (ed.) Estuarine interactions. Academic Press, New York, p. 115-130

Taft, J. L., Hartwig, E. O., Loftus, R. (1980). Seasonal oxygen depletion in Chesapeake Bay. Estuaries 3: 242-247

Tyler, M. A. (1984). Dye tracing of a subsurface chlorophyll maximum of a red-tide dinoflagellate to surface frontal regions. Mar. Biol. 78: 285-300

Walsh, J. J., Rowe, G. T., Iverson, R. E., McRoy, C. P. (1981). Biological export of shelf carbon is a sink of the global $\mathrm{CO}_{2}$ cycle. Nature, Lond. 291: 196-201

Ward, L. G., Twilley, R. R. (1986). Seasonal distributions of suspended particulate material and dissolved nutrients in a coastal plain estuary. Estuaries 9: 156-168 